\title{
Fractional exhaled nitric oxide for the management of asthma in adults: a systematic review
}

\author{
Munira Essat ${ }^{1}$, Sue Harnan ${ }^{1}$, Tim Gomersall ${ }^{1}$, Paul Tappenden ${ }^{1}$, Ruth Wong ${ }^{1}$, \\ Ian Pavord ${ }^{2}$, Rod Lawson ${ }^{3}$ and Mark L. Everard ${ }^{4}$
}

Affiliations: ${ }^{1}$ School of Health and Related Research, University of Sheffield, Sheffield, UK. ${ }^{2}$ Nuffield Dept of Medicine, University of Oxford, Oxford, UK. ${ }^{3}$ Dept of Respiratory Medicine, Royal Hallamshire Hospital, Sheffield, UK. ${ }^{4}$ School of Paediatrics and Child Health, Princess Margaret Hospital, University of Western Australia, Perth, Australia.

Correspondence: Munira Essat, School of Health and Related Research, University of Sheffield, Regent Court, 30 Regent Street, Sheffield, S1 4DA, UK. E-mail: m.essatđsheffield.ac.uk

ABSTRACT The aim of this review was to evaluate the clinical effectiveness of fractional exhaled nitric oxide $(F$ eNO) measured in a clinical setting for the management of asthma in adults.

13 electronic databases were searched and studies were selected against predefined inclusion criteria. Quality assessment was conducted using QUADAS-2. Class effect meta-analyses were performed.

Six studies were included. Despite high levels of heterogeneity in multiple study characteristics, exploratory class effect meta-analyses were conducted. Four studies reported a wider definition of exacerbation rates (major or severe exacerbation) with a pooled rate ratio of 0.80 (95\% CI 0.63-1.02). Two studies reported rates of severe exacerbations (requiring oral corticosteroid use) with a pooled rate ratio of 0.89 (95\% CI 0.43-1.72). Inhaled corticosteroid use was reported by four studies, with a pooled standardised mean difference of -0.24 (95\% CI $-0.56-0.07)$. No statistically significant differences for health-related quality of life or asthma control were found.

FeNO guided management showed no statistically significant benefit in terms of severe exacerbations or inhaled corticosteroid use, but showed a statistically significant reduction in exacerbations of any severity. However, further research is warranted to clearly define which management protocols (including cut-off points) offer best efficacy and which patient groups would benefit the most.

@ERSpublications

FeNO testing for adult asthma management may confer clinical benefit, but research is needed to establish its role http://ow.ly/WGWkx

This article has supplementary material available from erj.ersjournals.com

Received: Nov 122015 | Accepted after revision: Dec 062015 | First published online: Feb 042016

Support statement: This project was funded by the National Institute for Health Research Health Technology Assessment (NIHR HTA) Programme (project number: 12/60/01) as part of a review on "Measurement of exhaled nitric oxide concentration in asthma; NIOX MINO, NIOX VERO and Nobreath", and published as part of a full report in Health Technology Assessment (PROSPERO registration number: CRD42013004149 (www.crd.york.ac.uk/prospero/)). The views and opinions expressed therein are those of the authors and do not necessarily reflect those of the NHS, the NIHR, MRC, CCF, NETSCC, the NIHR HTA programme or the UK Department of Health. Funding information for this article has been deposited with FundRef.

Conflict of interest: Disclosures can be found alongside the online version of this article at erj.ersjournals.com

Copyright CERS 2016. ERJ Open articles are open access and distributed under the terms of the Creative Commons Attribution Non-Commercial Licence 4.0. 


\section{Introduction}

Asthma is a chronic disorder of the airways, caused primarily by inflammatory processes and bronchoconstriction. Poorly controlled asthma can have a significant impact on the quality of life of the affected individual and their family. An estimated 5.4 million people in the UK are currently receiving treatment for asthma [1, 2]. Despite the high prevalence rates, deaths resulting from asthma are uncommon.

The pharmacological management of asthma in adults aims to control symptoms (including nocturnal symptoms and exercise induced asthma), prevent exacerbations and achieve the best possible lung function, with minimal side-effects of treatment. Inhaled corticosteroids (ICSs) are the main treatment for asthma, and although at low dosage the side-effects are few, high dosage or long-term use of ICS is associated with an increased risk of systemic side-effects [3]. The current British guidelines on the management of asthma recommend a stepwise approach, with escalation of medication until control is reached or stepping down when control is good [4]. However, in certain cases there is suspected over- and under-treatment.

Fractional exhaled nitric oxide $(\mathrm{FeNO})$ is a noninvasive biomarker of airway inflammation in asthma. High FeNO in the breath of patients with symptoms of asthma are correlated with eosinophilic airway inflammation (a distinct corticosteroid responsive phenotype of asthma) [5-7]. The presence of eosinophils may be used to direct treatment as patients without eosinophilic inflammation are thought to be less responsive to ICS treatment [8]. Therefore, in order to reach a balance between treatment and control, the addition of FeNO monitoring might allow optimisation of treatment in the different disease phenotypes. Existing reviews of FeNO monitors suggest some benefits associated with FeNO [9-11]; however, none were statistically conclusive. In addition, these reviews focused on number of people with an exacerbation, inappropriately included the cohort of pregnant women in the meta-analysis (pregnancy can substantially affect the course of asthma) [12] and are out-of-date. To address these limitations we have updated an existing review [9], with the addition of three new studies [13-16], to determine the potential role of FeNO monitors in the management and monitoring of asthma in adults. This systematic review was undertaken to inform a UK National Institute for Health and Care Excellence appraisal which included an assessment of the use of the electrochemical FeNO monitors NIOX MINO (Aerocrine AB, Solna, Sweden), NIOX VERO (Aerocrine AB) and NObreath (Bedfont Scientific Ltd, Maidstone, UK) in the diagnosis and management of asthma $[17,18]$.

\section{Methods}

A systematic review was undertaken in accordance with the general principles recommended in the Preferred Reporting Items for Systematic Reviews and Meta-Analyses statement [19].

\section{Data sources and searches}

13 electronic databases and research registers were searched (including MEDLINE and the Cochrane Library) between March and April 2013, with update searches conducted in September 2013 and November 2014. Terms for NIOX VERO, a new FeNO device, were added to the strategy in August 2013. The search strategy used free-text terms and subject headings for the tests (e.g. NIOX MINO, NObreath and $\mathrm{FeNO}$ ) combined with keywords for the condition (i.e. asthma or lower respiratory tract symptoms). No language restrictions were applied. As part of updating an earlier systematic review [9], searches were limited by date from 2009 (the last search date from the earlier review). Searches were supplemented by hand-searching reference lists of relevant studies and contact with experts in the field. Further details of the search strategy are provided in the online supplementary appendix 1.

\section{Study selection}

All titles were examined for inclusion by one reviewer and any citations that did not meet the inclusion criteria (e.g. non-human or unrelated to asthma) were excluded. All abstracts and full-text articles were then examined independently by two reviewers. Any disagreements in the selection process were resolved through discussion. Details of the selection criteria are provided in table 1 . This review focuses on studies relating to adults only. Details of FeNO for the management of asthma in children have been published elsewhere [21].

\section{Data abstraction}

Data relating to study design, patient characteristics and outcomes were extracted by one reviewer into a standardised data extraction form and independently checked for accuracy by a second reviewer. Any discrepancies were resolved through discussion. Where necessary, study authors were contacted for missing information or additional data. 
TABLE 1 Study selection criteria

\section{Inclusion}

Adults ( $\geqslant 18$ years) with diagnosis of asthma including pregnant women.

\section{Intervention}

\section{Comparator}

\section{Outcome}

\section{Study type}

Studies that measured FeNO according to the ATS 2005 criteria [20] for the management of asthma, either with or without other indicators of asthma control. ATS criteria relating to multiple testing were relaxed to allow inclusion of studies that operated electrochemical devices in line with the manufacturer's instructions, which state only one test is required. Studies where monitoring was performed at home were excluded as this was not within the scope of the assessment.

Studies comparing the intervention to any other management strategy that does not utilise $F_{\mathrm{eNO}}$ measurements.

Primary outcome of interest included incidence of acute exacerbation lany definition of exacerbation severity was acceptable, including "use of oral corticosteroids"), inhaled corticosteroid use, unscheduled contact with healthcare officials, hospitalisations and emergency department visits expressed or calculable as rates per person year or as the number of patients experiencing exacerbations. These outcomes were chosen as they have the greatest impact both clinically and economically.

Other outcomes included clinical complications associated with acute exacerbation, asthma control and symptoms, adverse events, health-related quality of life, mortality and compliance.

\section{Exclusion}

Studies that included cohorts

with a mean age $<18$ years of age

Recruited patients were not

diagnosed with asthma

Animal models

Unselected specific population

(e.g. firefighters, obese or athletes)

Device which is not validated for measuring FeNO Offline measurements

Studies where $F_{\mathrm{eNO}}$ is measured on a more regular basis (i.e. not during a routine annual review)

Includes the use of $F_{\text {eNO }}$ measurement as part of the management strategy

Does not report data on FenO-guided step-up/ step-down therapy

Measure of alveolar nitric oxide or nasal nitric oxide
Preclinical and biological studies

Editorials and opinion pieces

Studies only published in languages other than English

\section{Assessment of methodological quality}

The methodological quality of each included study was assessed according to the Cochrane Collaboration's tool for assessing the risk of bias in randomised controlled trials (RCTs) [22]. The studies were assessed by one reviewer and independently checked by another.

\section{Data synthesis and analysis}

Data were tabulated and discussed in a narrative review. Meta-analyses were planned, where appropriate, to estimate a summary measure of effect on relevant outcomes using the methods documented in the Cochrane Handbook $[22,23]$. For rate outcomes, rates per person year were the preferred outcome metric, as this accounts for multiple events in a single patient. The generic inverse variance method was used to meta-analyse rate ratios using Review Manager software (Version 5.3. The Nordic Cochrane Centre, The Cochrane Collaboration, 2014). For continuous outcomes, a standardised mean difference analysis was conducted where outcomes were not reported in a standardised way. In all cases, fixed effects were used first, and random effects applied if the $\mathrm{I}^{2}$ statistic indicated that heterogeneity was moderate or high. This was judged to be the case at $>40 \%$. Studies in pregnant women were analysed separately as FeNO may be affected by pregnancy [12]. 
TABLE 2 Study and population characteristics

\begin{tabular}{|c|c|c|c|c|c|c|c|c|c|c|}
\hline $\begin{array}{l}\text { First } \\
\text { author } \\
\text { [ref.] }\end{array}$ & $\begin{array}{l}\text { Country, funding } \\
\text { details }\end{array}$ & Study design & $\begin{array}{l}\text { Inclusion/exclusion } \\
\text { criteria }\end{array}$ & $\begin{array}{l}\text { Subjects } \\
\quad \text { analysed/ } \\
\text { recruited } \mathrm{n} / \mathrm{N}\end{array}$ & Age years & $\begin{array}{l}\text { Males } n / N \\
(\%)\end{array}$ & Spirometry & Severity & Feno & $\begin{array}{l}\text { Smokers; } \\
\text { Atopic; } \\
\text { Medication use }\end{array}$ \\
\hline $\begin{array}{l}\text { SMITH } \\
\text { [24] }\end{array}$ & $\begin{array}{l}\text { New Zealand, } \\
\text { Mixed funding } \\
\text { including } \\
\text { equipment } \\
\text { from Aerocrine }\end{array}$ & $\begin{array}{l}\text { RCT: single blind, } \\
\text { single centre, } \\
\text { placebo-controlled }\end{array}$ & $\begin{array}{l}\text { Chronic asthma [27] } \\
\text { managed in primary care; } \\
\text { regular ICS for } \\
\geqslant 6 \text { months, no dose } \\
\text { change in previous } \\
6 \text { weeks. If could not } \\
\text { tolerate removal of LABA } \\
\text { during run-in allowed to } \\
\text { participate if could } \\
\text { tolerate a fixed dose. } \\
\text { Exclusions: } \geqslant 4 \text { courses oral } \\
\text { prednisone in previous } \\
12 \text { months; admission to } \\
\text { hospital for asthma in } \\
\text { previous } 6 \text { months; ever } \\
\text { admitted to IC for } \\
\text { asthma; smokers } \\
\text { (current or ex-) with a } \\
\text { history of }>10 \text { pack-years. }\end{array}$ & $\begin{array}{l}94 / 110 \\
\text { WBR: 13; } \\
\text { Intervention } \\
\text { group: } 46 / 48 \\
\text { Control group: } \\
\quad 48 / 49\end{array}$ & $\begin{array}{l}\text { Mean age } \\
44.8 \text { (range } \\
12-73 \text { ) }\end{array}$ & $\begin{array}{l}41 / 110 \\
(37.3 \%)\end{array}$ & $\begin{array}{l}\text { Mean (range) } \\
\text { FEV } \% \text { pred } \\
\text { Intervention } \\
\text { group: } \\
86.4 \text { (80.6-92.2) } \\
\text { Control } \\
\text { group: } 83.1 \\
\text { (76.5-89.7) }\end{array}$ & $\begin{array}{l}\text { Mean }(95 \% \mathrm{Cl}) \\
\text { symptom } \\
\text { score } \\
\text { Intervention } \\
\text { group: } 0.6 \\
(0.4-0.8) \\
\text { Control } \\
\text { group: } \\
0.8(0.6-1.1)\end{array}$ & $\begin{array}{l}\text { GM }(95 \% \mathrm{Cl}) \\
\text { Feno } 250 \mathrm{~mL}^{+} \\
\text {Intervention } \\
\text { group: } \\
7.8(6.6-9.3) \\
\text { Control group: } \\
6.4(5.5-7.5)\end{array}$ & $\begin{array}{l}\text { Smokers: None } \\
\text { Atopic: NR } \\
\text { Medication use: } \\
\text { Bronchodilator use, } \\
\text { mean per day over } \\
\text { the previous } \\
7 \text { days }(95 \% \mathrm{CI}) \\
\text { Intervention group: } \\
0.5(0.2-0.8) \\
\text { Control group: } \\
0.6(0.3-0.8) \\
\text { ICS use NR }\end{array}$ \\
\hline $\begin{array}{l}\text { SHAW } \\
\text { [25] }\end{array}$ & $\begin{array}{l}\text { UK, } \\
\text { Asthma UK } \\
\text { grant, speakers } \\
\text { fees reported, } \\
\text { but not from } \\
\text { Aerocrine }\end{array}$ & $\begin{array}{l}\text { RCT: single blind, } \\
\text { parallel group }\end{array}$ & $\begin{array}{l}\text { GP diagnosis of asthma } \\
\text { with } \geqslant 1 \text { prescription for } \\
\text { anti-asthma medication } \\
\text { in the past } 12 \text { months. } \\
\text { Current nonsmokers with } \\
\text { a past smoking history of } \\
<10 \text { pack-years. } \\
\text { Exclusions: poorly } \\
\text { compliant; those with a } \\
\text { severe asthma } \\
\text { exacerbation (needing } \\
\text { prednisolonel in the } \\
\text { previous } 4 \text { weeks. }\end{array}$ & $\begin{array}{l}118 \text { (ITT } \\
\text { LOCF)/119 } \\
\text { WBR: } 1 \\
\text { Intervention } \\
\text { group: } 58 \\
\text { Control } \\
\text { group: } 60\end{array}$ & $\begin{array}{l}\text { Adults } \\
>18 \text { years } \\
\text { Mean age NR }\end{array}$ & $\begin{array}{l}54 / 118 \\
(46 \%)\end{array}$ & $\begin{array}{l}\text { Mean } \pm \text { SD } \\
\text { FEV } \% \text { pred } \\
\text { Intervention } \\
\text { group: } \\
81.4 \pm 20.9 \\
\text { Control group: } \\
84.9 \pm 20.1 \\
\text { Mean } \pm \text { SD } \mathrm{FEV} / / \mathrm{FVC} \\
\text { Intervention } \\
\text { group: } \\
71 \pm 10.7 \\
\text { Control group: } \\
72 \pm 9.9\end{array}$ & $\begin{array}{l}\text { Mean } \pm \text { sD } \\
\text { Juniper } \\
\text { score } \\
\text { Intervention } \\
\text { group: } \\
1.32 \pm 0.65 \\
\text { Control } \\
\text { group: } \\
1.26 \pm 0.75\end{array}$ & $\begin{array}{l}\mathrm{GM}(68 \% \mathrm{Cl}) \\
\text { log } F_{\mathrm{eNO}} \\
\text { Intervention } \\
\text { group: } 29.2 \\
\text { (14.0-61.0) } \\
\text { Control } \\
\text { group: } 31.2 \\
\text { (13.3-73.1) }\end{array}$ & $\begin{array}{l}\text { Ex-smokers: } \\
\text { Intervention } \\
\text { group: } 22 \% \\
\text { Control group: 25\% } \\
\text { Atopic:78 (66.1\%) } \\
\text { out of } 118 \\
\text { Medication use: } \\
\text { Mean } \pm \text { sD ICS } \\
\text { daily dose } \\
\text { Intervention group: } \\
697 \pm 708 \mu \mathrm{g} \\
\text { Control group: } \\
652 \pm 533 \mu \mathrm{g}\end{array}$ \\
\hline SYK [14] & $\begin{array}{l}\text { Sweden, } \\
\text { Mixed funding }{ }^{\#} \text {, } \\
\text { some from } \\
\text { Aerocrine }\end{array}$ & $\begin{array}{l}\text { RCT: open label, } \\
\text { parallel group, } \\
\text { multicentre }\end{array}$ & $\begin{array}{l}\text { Doctor's diagnosis of } \\
\text { asthma and ICS } \\
\text { treatment for } \\
\geqslant 6 \text { months, IgE } \\
\text { sensitisation to at least } \\
\text { one major airborne } \\
\text { perennial allergen. } \\
\text { Nonsmokers for } \geqslant 1 \text { year } \\
\text { and with smoking history } \\
\text { of }<10 \text { pack-years. } \\
\text { Patients all had mild to } \\
\text { moderate asthma. }\end{array}$ & $\begin{array}{l}\text { 165/187 } \\
\text { WBR: } 6 \\
\text { Intervention } \\
\quad \text { group: 87/93 } \\
\text { Control } \\
\quad \text { group: 78/88 }\end{array}$ & $\begin{array}{l}\text { Adults } \\
\text { (18-64 years) } \\
\text { Mean } \pm \text { SD } \\
\quad 41 \pm 12.4\end{array}$ & $\begin{array}{l}94 / 181 \\
(51.9 \%)\end{array}$ & $\begin{array}{l}\text { Mean } \pm \text { SD } \\
\text { FEV } 1 \% \text { pred } \\
\text { Intervention } \\
\text { group: } 84.3 \pm 14.1 \\
\text { Control group: } \\
83.7 \pm 12.5 \\
\text { Mean } \pm \text { SD } \\
\text { FEV } 1 / \text { FVC } \\
\text { Intervention } \\
\text { group: } 0.78 \pm 0.08 \\
\text { Control group: } \\
0.79 \pm 0.08\end{array}$ & NR & $\begin{array}{l}\text { GM }(95 \% \mathrm{Cl}) \\
\text { FeNo ppb } \\
\text { Intervention } \\
\text { group: 22.0 } \\
\text { (19.3-25.2) } \\
\text { Control } \\
\text { group: 21.6 } \\
\text { (18.7-25.0) }\end{array}$ & $\begin{array}{l}\text { Smokers: None } \\
\text { Atopic: } 165(100 \%) \\
\text { out of } 165 \\
\text { Medication use: } \\
\text { Median (IQR) } \\
\text { budesonide } \\
\text { equivalent } \\
\text { ICS dose } 400 \\
\text { (400-800) } \mu \text { g.day }{ }^{-1} \\
\text { LABA before study } \\
\text { entry } 54(30.0 \%) \\
\text { out of } 180\end{array}$ \\
\hline
\end{tabular}




\begin{tabular}{|c|c|c|c|c|c|c|c|c|c|c|}
\hline $\begin{array}{l}\text { First } \\
\text { author } \\
\text { [ref.] }\end{array}$ & $\begin{array}{l}\text { Country, funding } \\
\text { details }\end{array}$ & Study design & $\begin{array}{l}\text { Inclusion/exclusion } \\
\text { criteria }\end{array}$ & $\begin{array}{l}\text { Subjects } \\
\quad \text { analysed/ } \\
\text { recruited } n / N\end{array}$ & Age years & $\begin{array}{l}\text { Males } \mathrm{n} / \mathrm{N} \\
{[\%]}\end{array}$ & Spirometry & Severity & Feno & $\begin{array}{l}\text { Smokers; } \\
\text { Atopic; } \\
\text { Medication use }\end{array}$ \\
\hline $\begin{array}{l}\text { Calнoun } \\
\text { [13] }\end{array}$ & $\begin{array}{l}\text { USA, } \\
\text { Mixed funding }{ }^{\#} \text {, } \\
\text { equipment from } \\
\text { Aerocrine }\end{array}$ & $\begin{array}{l}\text { RCT: } \\
\text { multiply-blinded, } \\
\text { multicentre } \\
\text { study }\end{array}$ & $\begin{array}{l}\text { Mild to moderate } \\
\text { asthmatics, well } \\
\text { controlled persistent } \\
\text { asthma with compliance } \\
\text { rates } \geqslant 75 \% \text {, who could } \\
\text { tolerate treatment of two } \\
\text { puffs twice daily of } \\
\text { beclomethasone HFA } \\
\left(40 \mu \mathrm{g} \cdot \text { puff }^{-1}\right) \text { during the } \\
2 \text { week run-in period. }\end{array}$ & $\begin{array}{l}363 \text { recruited } \\
\quad \text { to trial } \\
\text { WBR: } 21 \\
\text { Intervention } \\
\text { group: } \\
115 / 115^{\S} \\
\text { Control group: } \\
\text { 114/114 } \\
\text { Other study arm } \\
\text { (not included } \\
\text { in review): } \\
113 / 113\end{array}$ & $\begin{array}{l}\text { Mean } \pm \text { SD: } \\
\text { Intervention } \\
\text { group: } \\
34.8 \pm 11.3 ; \\
\text { Control group: } \\
34.2 \pm 11.9\end{array}$ & $\begin{array}{l}75 / 229 \\
(32.8 \%)\end{array}$ & $\begin{array}{l}\text { Mean } \pm \text { SD } \\
\text { FEV } 1 \% \text { pred } \\
\text { Intervention } \\
\text { group: } \\
86.3 \pm 10.4 \\
\text { Control group: } \\
87.7 \pm 12.1\end{array}$ & $\begin{array}{l}\text { Mean } \pm \text { SD } \\
\text { ACQ score } \\
\text { Intervention } \\
\text { group: } \\
0.79 \pm 0.54 \\
\text { Control group: } \\
0.72 \pm 0.50 \\
\text { Mean } \pm \text { SD AQLQ } \\
\text { score } \\
\text { Intervention } \\
\text { group: } \\
6.16 \pm 0.77 \\
\text { Control group: } \\
6.27 \pm 0.76 \\
\text { Mean } \pm \text { sD ASUI } \\
\text { score } \\
\text { Intervention } \\
\text { group: } \\
0.88 \pm 0.12 \\
\text { Control group: } \\
0.90 \pm 0.10\end{array}$ & $\begin{array}{l}\mathrm{GM} \pm \mathrm{SD} F_{\mathrm{eNO}} \mathrm{ppb} \\
\text { Intervention } \\
\text { group: } \\
18.88 \pm 0.66 \\
\text { Control group: } \\
21.38 \pm 0.62\end{array}$ & $\begin{array}{l}\text { Smokers: NR } \\
\text { Atopic: } \\
196 \text { (85.6\%) } \\
\text { out of } 229 \\
\text { Medication use: } \\
\text { Albuterol rescue } \\
\text { use median (IQR) } \\
\text { Intervention } \\
\text { group: } \\
0.07 \text { (0-0.43) } \\
\text { Control group: } \\
0.04(0-0.29)\end{array}$ \\
\hline $\begin{array}{c}\text { HonkOOP } \\
\text { [16] }\end{array}$ & $\begin{array}{l}\text { The Netherlands, } \\
\text { Mix of } \\
\text { non-commercial } \\
\text { grants and } \\
\text { funding from } \\
\text { Aerocrine }\end{array}$ & RCT; cluster design & $\begin{array}{l}\text { From protocol: doctor's } \\
\text { diagnosis of asthma; who } \\
\text { need ICS as controller } \\
\text { medication (step 2-4 } \\
\text { GINA guidelines); ICS } \\
\geqslant 3 \text { months in the } \\
\text { previous year; no } \\
\text { exacerbation of asthma } \\
\text { within } 1 \text { month before } \\
\text { entry. Exclusions: daily or } \\
\text { alternate day oral } \\
\text { corticosteroid therapy for } \\
\text { at least } 1 \text { month before } \\
\text { entering into the study. }\end{array}$ & $\begin{array}{l}611 \text { randomised } \\
\text { Other data NR } \\
\text { Intervention } \\
\text { group: } \\
\text { 189/205 } \\
\text { Controlled } \\
\text { asthma: } \\
\text { 219/232 } \\
\text { Partly controlled } \\
\text { asthma: } \\
\text { 203/210 }\end{array}$ & $\begin{array}{l}\text { Mean } \pm \text { SD age: } \\
39.4 \pm 9.5 \\
\text { Intervention } \\
\text { group: } \\
39.5 \pm 9.3 \\
\text { Controlled } \\
\text { asthma: } \\
38.9 \pm 9.3 \\
\text { Partly } \\
\text { controlled } \\
\text { asthma: } \\
39.9 \pm 9.8\end{array}$ & $\begin{array}{l}\text { 190/611 } \\
\text { (31\%) } \\
\text { Intervention } \\
\text { group: } \\
27.7 \% \\
\text { Controlled } \\
\text { asthma: } \\
31.6 \% \\
\text { Partly } \\
\text { controlled } \\
\text { asthma: } \\
34.2 \%\end{array}$ & $\begin{array}{l}\text { Mean } \pm \text { SD } \\
\text { FEV } \% \text { pred } \\
\text { Intervention } \\
\text { group: } \\
\text { 93.1 } \pm 17.0 \\
\text { Controlled } \\
\text { asthma: } \\
92.4 \pm 17.2 \\
\text { Partly controlled } \\
\text { asthma: } \\
93.0 \pm 17.0\end{array}$ & 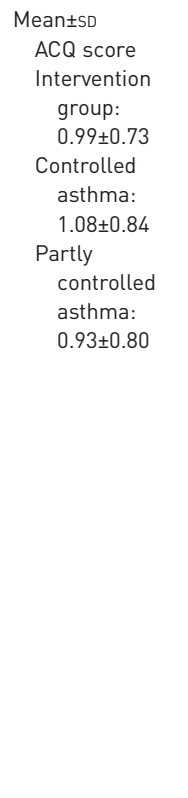 & $\begin{array}{l}\text { Mean } \pm \text { SD } \\
\text { FeNo ppb } \\
\text { Intervention } \\
\text { group: } \\
24.5 \pm 21.7 \\
\text { Controlled } \\
\text { asthma: } \\
27.3 \pm 30.4 \\
\text { Partly } \\
\text { controlled } \\
\text { asthma: } \\
24.7 \pm 29.8\end{array}$ & $\begin{array}{l}\text { Smokers: } \\
\text { Intervention } \\
\text { group: } 14 \% \\
\text { Controlled } \\
\text { asthma: } 13 \% \\
\text { Partly controlled } \\
\text { asthma: } 16 \% \\
\text { Atopic: } 322 \text { [54\%] } \\
\text { out of } 611 \\
\text { Medication use: } \\
\text { LABA: } \\
\text { Intervention } \\
\text { group: } 47 \% \\
\text { Controlled } \\
\text { asthma: } 49 \% \\
\text { Partly controlled } \\
\text { asthma: } 52 \% \\
\text { Mean } \pm \text { SD } \\
\text { beclomethasone } \\
\text { equivalent dose: } \\
\text { Intervention } \\
\text { group: } 853 \pm 642 \mu \mathrm{g} \\
\text { Controlled } \\
\text { asthma: } \\
831 \pm 701 \mu \mathrm{g} \\
\text { Partly controlled } \\
\text { asthma: } 825 \pm 639 \mu \mathrm{g}\end{array}$ \\
\hline
\end{tabular}




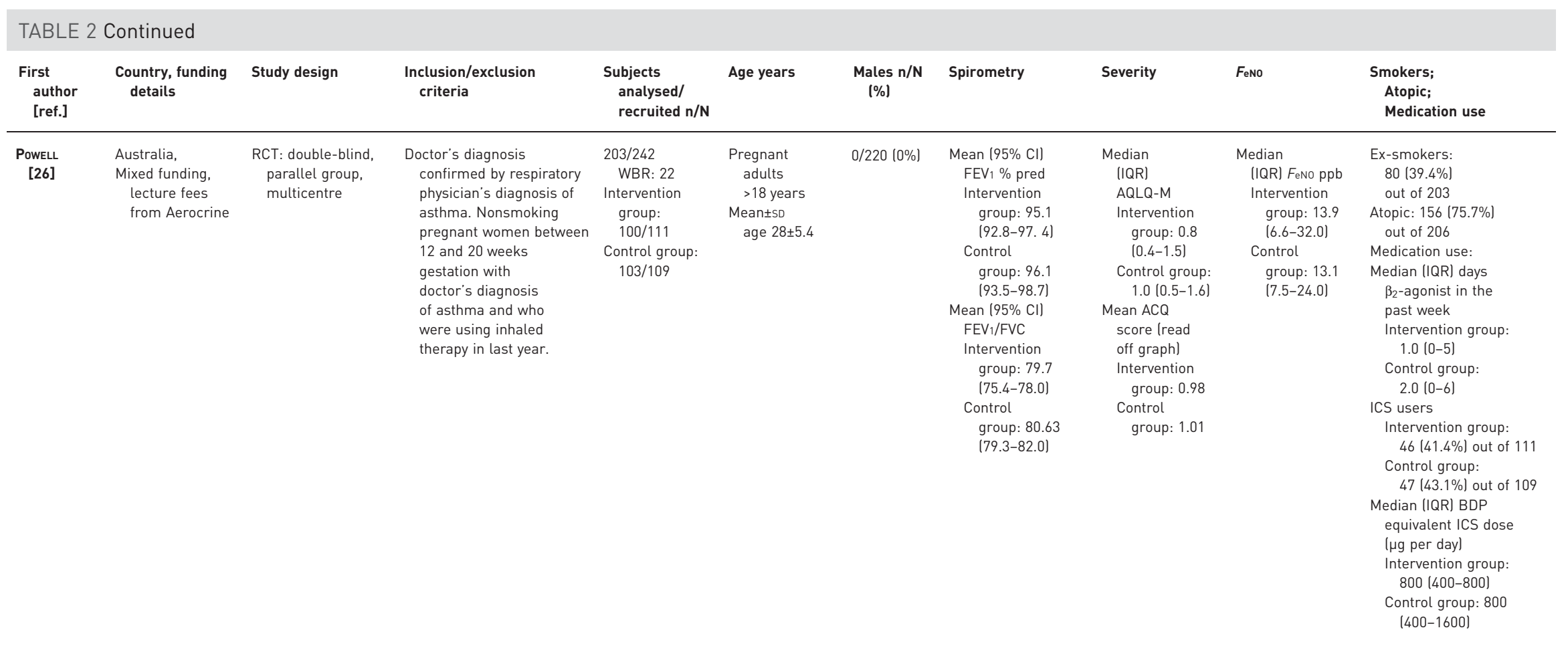

FeNO: fractional exhaled nitric oxide; RCT: randomised controlled trial; ICS: inhaled corticosteroid; LABA: long-acting $\beta_{2}$-agonist; IC: intensive care; WBR: withdrew before randomisation; FEV1: forced expiratory volume in $1 \mathrm{~s}$; GM: geometric mean; NR: not reported; GP: general practitioner; ITT: intention to treat; LOCF: last observation carried forward; FVC: forced vital capacity; IQR: interquartile range; HFA: hydrofluoroalkanes; ACQ: Asthma Control Questionnaire; AQLQ: Asthma Quality of Life Questionnaire; ASUI: Asthma Symptom Utility Index; GINA: Global Initiative for Asthma; AQLQ-M; Asthma Quality of Life Questionnaire-Marks; BDP: beclomethasone dipropionate. " : mix of industry and non-industry funding, e.g. research council grants. ": daily score over the previous 7 days. Asthma symptoms were scored for each 24-h period as follows: 0 , indicated no symptoms; 1 , symptoms for one short period; 2 , symptoms for two or more short periods; 3 , symptoms most of the time that did not affect normal daily activities; 4, symptoms most of the time that did affect normal daily activities; and 5 , symptoms so severe as to disrupt daily activities. ${ }^{+}$: FeNo measured at $250 \mathrm{~mL} \cdot \mathrm{s}^{-1}$ gives lower values than $F_{\mathrm{eNO}}$ at $50 \mathrm{~mL} \cdot \mathrm{s}^{-1} .^{\S}: 37$ withdrew, imputation method NR. $f: 13$ withdrew, imputation method NR. 


\section{Results}

\section{Trial flow}

Of the 5354 citations identified, three RCTs $[13,14,16]$ met the inclusion criteria and were added to the three existing trials [24-26] identified in the previous systematic reviews $[9,11]$. The majority of the excluded articles did not use FeNO to guide step-up/step-down therapy or the study design was not an RCT. A summary of the process of identifying and selecting the relevant literature can be found in online supplementary appendix 2 .

\section{Characteristics of included studies}

Table 2 presents the study characteristics of the six included studies [13, 14, 16, 24-26]. All the included studies compared FeNO-guided asthma management to non-FeNO-guided management and all patients were recruited in primary care, except for CALHOUN et al. [13], where the recruitment setting was unclear. The device used to measure FeNO was not clearly reported in three studies. Most studies were of a small to moderate size, with the number of patients ranging from 94 [24] to 611 [16]. All studies recruited adults of either sex [13, 14, 16, 24, 25], apart from Powell et al. [26], which recruited only pregnant women. The comparability of study populations in terms of severity at baseline is difficult to determine as different scales for severity and different metrics for medication use were reported. Inclusion and exclusion criteria suggest that at least four studies $[13,14,24,26]$ recruited populations with mild to moderate asthma; while the other two studies $[16,25]$ included a broader spectrum of severity. However, overall the patient population is predominantly milder asthmatics (mean forced expiratory volume in $1 \mathrm{~s}$ (FEV1) range $81-96 \%$ predicted). In addition, no studies followed the same timeline, visit frequency, management protocols, number and points of FeNO cut-offs, and treatment doses varied across the included studies (table 3 ).

\section{Risk of bias within studies}

Table 4 summarises the methodological quality of the included studies. Generally, two studies [25, 26] performed well receiving a positive assessment of at least six of the seven quality items. The most frequently identified potential sources of a high risk of bias concerned "other biases" related to the receipt of commercial funding (67\%) $[13,14,16,24]$. A high number of publications poorly reported the following aspects: random sequence generation $(33 \%)[13,24]$, allocation concealment $(33 \%)[13,24]$ and blinding of outcome assessment $(50 \%)[13,24,25]$. It should be noted that poor performance in quality assessment for the study by SYK et al. [14] was due to its open label study design, which was necessary to influence patients' adherence to treatment and to capture these clinically valuable effects.

\section{Outcomes and synthesis of results}

Despite wide variation in all aspects of study design across the five studies [13, 14, 16, 24, 25] (excluding the study on pregnant women) [26]; exploratory meta-analyses were conducted where possible for all relevant outcomes (table 5).

\section{Healthcare utilisation}

Unscheduled healthcare utilisation, defined as emergency department/accident and emergency visits, out-of-hours general practitioner's surgery visits or hospitalisation, was only reported in HonkOOP et al. [16]. Although the result showed improvement in healthcare utilisation with FeNO management (table 5), this was not statistically significant for all comparisons $(p>0.05)$. In the remaining four studies $[13,14,24,25]$, unscheduled healthcare utilisation was included as either treatment failure or severe exacerbations (see later), since exacerbations of asthma can lead to both unscheduled healthcare utilisation and the need for a course of oral corticosteroids (OCSs).

\section{Severe exacerbations}

This outcome was defined differently across studies (table 5). Syк et al. [14] and Honkoop et al. [16] defined it as "worsening requiring a course of OCS"; SHAW et al. [25] defined it as "exacerbations resulting in the use of OCS or antibiotics"; and CALHOUn et al. [13] reported it as "exacerbations", which included exacerbations leading to OCS use, increased ICS use or additional medication for asthma. A meta-analysis of four studies (the study of SMITH et al. [24] was not included as follow-up data were not calculable as rates per person year) showed that severe exacerbations (while statistically not significant) were less likely in the FeNO-guided-management group compared with the control group (figure 1a), with rate ratio of 0.80 (95\% CI $0.63-1.02 ; \mathrm{p}=0.08)$.

Severe exacerbations resulting in the use of OCS

Analysis of studies reporting the number of severe exacerbations resulting in the use of OCS (figure 1b) was limited to only two studies $[14,16]$, which showed opposite directions of effect. This may be due to variations in the step-up/step-down protocols employed in the studies, or due to the populations being slightly different. 
TABLE 3 Description of management strategies

\begin{tabular}{|c|c|c|c|c|}
\hline \multirow{2}{*}{$\begin{array}{l}\text { First author } \\
\text { [ref.] }\end{array}$} & \multicolumn{2}{|c|}{ Basis for decisions } & \multicolumn{2}{|c|}{ Treatments indicated } \\
\hline & Intervention & Control & Intervention & Control \\
\hline SMITH [24] & $\begin{array}{l}\text { FeNO, with a safety measure based on symptoms, } \\
\text { bronchodilator use and spirometry } \\
\text { FeNO }<35 \mathrm{ppb} \text { (equivalent at } 50 \mathrm{~mL} \cdot \mathrm{s}^{-1} \text { ) defined } \\
\text { as controlled asthma } \\
\text { FeNO } \geqslant 35 \mathrm{ppb} \text { defined as uncontrolled asthma } \\
\text { Safety measure: if one or more of the following } \\
\text { clinical criteria are met, increase one step: } \\
\text { 1) Symptom score for previous } 7 \text { days } \geqslant 1 \text { point } \\
\text { more than mean during run-in and } \\
\text { minimum score of } 2 \text { out of } 5 \\
\text { 2) Nocturnal wakening on } \geqslant 3 \text { nights per week } \\
\text { more than mean during run-in } \\
\text { 3) Mean daily bronchodilator use } \geqslant 3 \text { times } \\
\text { that of mean during run-in and minimum } \\
\text { use of } 15 \text { occasions during prior } 7 \text { days } \\
\text { 4) Diurnal peak flow variation } \geqslant 30 \% \text { and/or } \\
\text { FEV } 1 \text { of }<85 \% \text { of baseline }\end{array}$ & $\begin{array}{l}\text { GINA 2002: symptoms, } \\
\text { bronchodilator use, } \\
\text { spirometer }\end{array}$ & $\begin{array}{l}\text { Dose steps: placebo, inhaled fluticasone } \\
100 \mu \mathrm{g}, 250 \mu \mathrm{g}, 500 \mu \mathrm{g}, 750 \mu \mathrm{g} \text { and } 1000 \mu \mathrm{g} \\
\text { Phase 1: until optimal dose reached } \\
\text { Phase 2: up titrate one step at a time; down } \\
\text { titrate if controlled for two visits, but not } \\
\text { lower than optimal dose } \\
\text { Patients had personalised self-management } \\
\text { plans, which instructed them to take oral } \\
\text { prednisone } 40 \mathrm{mg} \text { per day when morning } \\
\text { peak flows fell below } 70 \% \text { of mean run-in } \\
\text { values, until it reached }>85 \% \text {, at which } \\
\text { time they took } 20 \mathrm{mg} \text { per day for the } \\
\text { same number of days }\end{array}$ & $\begin{array}{l}\text { As for intervention, but } \\
\text { without the personalised } \\
\text { management plan }\end{array}$ \\
\hline SHAW [25] & $\begin{array}{l}\text { FeNo plus symptoms (Juniper score) } \\
\text { Exhaled nitric oxide }<16 \text { ppb on first occasion or } \\
\text { exhaled nitric oxide } 16-26 \text { ppb on second } \\
\text { occasion with } \\
\text { 1) Juniper score } \leqslant 1.57 \text { : step-down } \\
\text { anti-inflammatory treatment, step-down } \\
\text { bronchodilator treatment once off steroids. } \\
\text { 2) Juniper score }>1.57 \text { : step-down } \\
\text { anti-inflammatory treatment, step-up } \\
\text { bronchodilator treatment } \\
\text { Exhaled nitric oxide }>26 \text { ppb with } \\
\text { 1) Juniper score } \leqslant 1.57 \text { : step-up } \\
\text { anti-inflammatory treatment, no change } \\
\text { in bronchodilator treatment } \\
\text { 2) Juniper score }>1.57 \text { : step-up } \\
\text { anti-inflammatory treatment, step-up } \\
\text { bronchodilator treatment once on maximum } \\
\text { anti-inflammatory treatment } \\
\text { Safety measure: patients on } 2000 \mu \mathrm{g} \\
\text { beclomethasone per day with }>26 \text { ppb Feno } \\
\text { and had not fallen to } 60 \% \text { of baseline had } \\
\text { sputum checked. If no eosinophilic } \\
\text { inflammation, treatment reduced stepwise, } \\
\text { unless Feno increased by }>60 \% \text { of baseline. }\end{array}$ & $\begin{array}{l}\text { BTS/SIGN guidelines using } \\
\text { Juniper scale to score } \\
\text { symptoms: } \\
\text { 1) treatment doubled } \\
\text { if score }>1.57 \\
\text { 2) treatment halved if } \\
\text { score }<1.57 \text { for } \\
2 \text { consecutive months }\end{array}$ & $\begin{array}{l}\text { Hierarchy of anti-inflammatory treatment: } \\
\text { 1) Low dose ICS (100-200 } \mu \mathrm{g} \text { BDP } \\
\text { twice daily) } \\
\text { 2) Moderate dose ICS (200-800 } \mu \mathrm{g} \text { BDP } \\
\text { twice daily) } \\
\text { 3) High dose ICS (800-2000 } \mu \mathrm{g} \text { BDP } \\
\text { twice daily) } \\
\text { 4) High dose ICS ( } 800-2000 \mu \mathrm{g} \text { BDP } \\
\text { twice daily) plus LTRA } \\
\text { 5) Higher dose ICS ( } 2000 \mu \mathrm{g} \text { BDP } \\
\text { twice daily) plus LTRA } \\
\text { 6) Higher dose ICS ( } 2000 \mu \mathrm{g} \text { BDP } \\
\text { twice daily) plus LTRA plus oral } \\
\text { prednisolone } 30 \text { mg for } 2 \text { weeks, then } \\
\text { titrate the dose reducing by } \\
5 \text { mg.week }{ }^{-1} \\
\text { Hierarchy of bronchodilator treatment } \\
\text { 1) SABA as needed } \\
\text { 2) LABA } \\
\text { 3) LABA plus theophylline } \\
\text { 4) LABA plus theophylline plus nebulised } \\
\text { bronchodilator }\end{array}$ & $\begin{array}{l}\text { Step 1: SABA as required } \\
\text { Step 2: Add ICS } \\
\text { 200-800 } \mu g^{-d a y}{ }^{-1} \\
\text { BDP equivalent } \\
\text { Step 3: Add inhaled LABA } \\
\text { Step 4: increase ICS up to } \\
2000 \mu \mathrm{g} \cdot \text { day }^{-1} \text { and } \\
\text { addition of fourth drug, } \\
\text { e.g. LTRA, theophylline } \\
\text { or LABA } \\
\text { Step 5: oral prednisolone, } \\
\text { high dose ICS, refer } \\
\text { to specialist care }\end{array}$ \\
\hline
\end{tabular}


TABLE 3 Continued

First author [ref.]

SYK [14]

FeNO only

$F_{\mathrm{eNO}}<19 \mathrm{ppb}$ (men), <21 ppb (women):

decrease one step

FeNo 19-23 ppb (men), 21-25 ppb (women): no change

$F_{\mathrm{eNO}} \geqslant 24 \mathrm{ppb}$ (men), $\geqslant 26 \mathrm{ppb}$ (women): increase one step (no change in treatment step

if on step 4 or 5 and using $\leqslant 2$ inhalations of SABA per week)

$F_{\mathrm{eNO}} \geqslant 30 \mathrm{ppb}$ (men), $\geqslant 32 \mathrm{ppb}$ (women): increase

two steps (only if on treatment step 1)

Grey zone of $5 \mathrm{ppb}$ applied to avoid frequent dose changes

\section{Calmoun [13]}

\section{FenO only}

Well controlled, $F_{\text {eNO }}<22 \mathrm{ppb}$ : down one level

Controlled, FeNO 22-35 ppb: maintain level

Under-controlled, FenO >35 ppb: up 1 level

\section{HoNKOOP [16]}

$\mathrm{ACQ}$ and $\mathrm{FeNO}$

Where ACQ $\leqslant 0.75$ with

1) $F_{\text {eNO }} \leqslant 25 \mathrm{ppb}$, step down

2) $F_{\mathrm{eNO}}>25 \mathrm{ppb}$ and $<50 \mathrm{ppb}$, no change

3) $F_{\mathrm{eNO}} \geqslant 50 \mathrm{ppb}$, step up

Where $A C Q>0.75$ and $<1.50$ with

1) $F_{\mathrm{eNO}} \leqslant 25 \mathrm{ppb}$ : and time $<3$ months,

no change, or change to LABA; if time

$>3$ months, step down ICS

2) $F_{\mathrm{eNO}}>25 \mathrm{ppb}$ and $<50 \mathrm{ppb}$ : step-up

(treatment choice)

3) $\mathrm{FeNO}_{\mathrm{eN}} \geqslant 50 \mathrm{ppb}$, step-up ICS by one level

Where ACQ $\geqslant 1.50$ with

1) $F_{\text {eNO }} \leqslant 25 \mathrm{ppb}$ : step-up LABA

2) $F_{\mathrm{eNO}}>25 \mathrm{ppb}$ and $<50 \mathrm{ppb}$ : step-up

(treatment choice)

3) $F_{\mathrm{eNO}} \geqslant 50 \mathrm{ppb}$ : step-up ICS by two levels

Treatments indicated

\section{Control}

Symptoms, lung function,

$\beta$-agonist use lusual care

Budesonide $\left(\mu \mathrm{g} \cdot \mathrm{day}^{-1}\right)$ :

Assume same doses

as intervention

$$
1600+\text { LTRA }
$$

Fluticasone $\left(\mu \mathrm{g} \cdot \mathrm{day}^{-1}\right): \mathbf{0}, 100$,

250, 500, 500+LTRA

1000+LTRA

Mometasone ( $\mu \mathrm{g} \cdot \mathrm{day}^{-1}$ )

0, 100, 200, 400, 400+LTRA,

$800+$ LTRA

NHLBI guidelines

(USA version of SIGN

guidelines)

\section{ACQ scores}

Strict strategy

ACQ $\leqslant 0.75:<3$ months,

no change; $>3$ months,

step-down

$A C Q>0.75$ and $<1.50$

Step-up: treatment choice

$A C Q \geqslant 1.50:$ Step-up:

treatment choice

Sufficient strategy

$A C Q \leqslant 0.75:$ Step-down

$A C Q>0.75$ and $<1.50$ :

No change

$A C Q \geqslant 1.50:$ Step-up:

treatment choice
Dosing beclomethasone HFA:

Level $1=0 \mu \mathrm{g}$ per day

Level $2=80 \mu \mathrm{g}$ once daily

Level $3=160 \mu \mathrm{g}$ twice daily

Level $4=320 \mu \mathrm{g}$ twice daily

Level $5=640 \mu$ g twice daily

Step 1: SABA as needed

Step 2: low-dose ICS; or LTRA

Step 3: low-dose ICS + LABA; or medium-

or high-dose ICS; or low-dose ICS+LTRA

Step 4: Add one or more of medium-

or high-dose ICS + LABA, and/or LTRA

Step 4: Add one or both of OCS (lowest dose),

anti-lgE treatment
As intervention

As intervention for both strategies 


\begin{tabular}{|c|c|c|c|c|}
\hline \multirow{2}{*}{$\begin{array}{l}\text { First author } \\
\text { [ref.] }\end{array}$} & \multicolumn{2}{|l|}{ Basis for decisions } & \multicolumn{2}{|c|}{ Treatments indicated } \\
\hline & Intervention & Control & Intervention & Control \\
\hline Powell [26] & 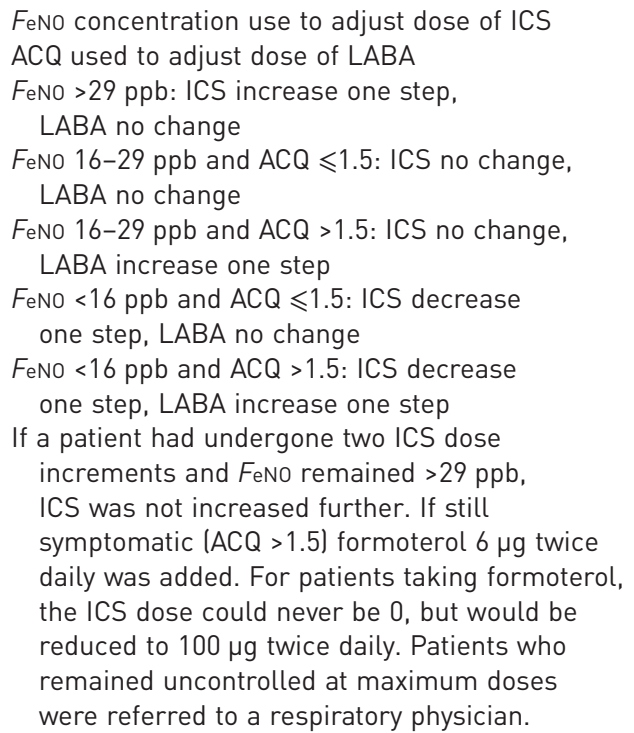 & $\begin{array}{l}\text { ACQ-guided } \\
\text { Well controlled asthma, } \\
\text { ACQ < } 0.75 \text { : reduce } \\
\text { treatment one step } \\
\text { Partially controlled asthma, } \\
\text { ACQ } 0.75-1.50 \text { : no } \\
\text { treatment change } \\
\text { Uncontrolled asthma, } \\
\text { ACQ }>1.5 \text { : increase one step } \\
\text { Those at maximum dose were } \\
\text { referred to a respiratory } \\
\text { physician }\end{array}$ & $\begin{array}{l}\text { Steps 1-5 } \\
\text { ICS: budesonide } 0,100,200,400 \text { or } \\
800 \mu \text { twice daily, respectively } \\
\text { LABA: } \\
\text { Step 1: salbutamol as required } \\
\text { Step 2-5: formoterol } 6,12,24 \text { or } \\
24 \mu \text { twice daily, respectively }\end{array}$ & $\begin{array}{l}\text { Step 1: salbutamol as } \\
\text { required } \\
\text { Step 2: budesonide } 200 \mu \mathrm{g} \\
\text { twice daily plus } \\
\text { salbutamol as required } \\
\text { Step 3: budesonide } 400 \mu \mathrm{g} \\
\text { twice daily plus } \\
\text { salbutamol as required } \\
\text { Step 4: budesonide } 400 \mu \mathrm{g} \\
\text { and formoterol } 12 \mu \mathrm{g} \\
\text { twice daily } \\
\text { Step 5: budesonide } 800 \mu \mathrm{g} \\
\text { twice daily and } \\
\text { formoterol } 24 \mu \mathrm{g} \\
\text { twice daily }\end{array}$ \\
\hline
\end{tabular}

FeNO: fractional exhaled nitric oxide; FEV1: forced expiratory volume in $1 \mathrm{~s}$; GINA: Global Initiative for Asthma; BTS: British Thoracic Society; SIGN: Scottish Intercollegiate Guidelines Network; HFA: hydrofluoroalkanes; ICS: inhaled corticosteroid; BDP: beclomethasone dipropionate; LTRA: leukotriene receptor antagonist; SABA: short-acting $\beta_{2}$-agonist; LABA: long-acting $\beta_{2}$-agonist; NHLBI: National Heart, Lung and Blood Institute; ACQ: Asthma Control Questionnaire; OCS: oral corticosteroid. 
TABLE 4 Risk of bias summary: review authors' judgements about each risk of bias item for each included study

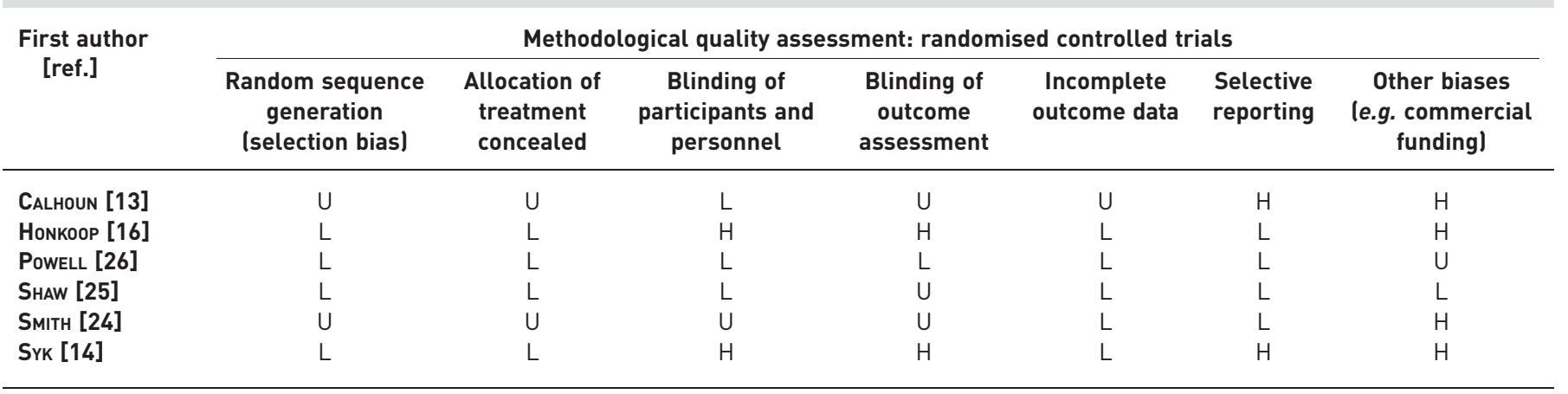

L: low risk of bias; $\mathrm{H}$ : high risk of bias; $\mathrm{U}$ : unclear risk of bias.

\section{Moderate and minor exacerbations}

Two studies $[14,24]$ reported data on less severe exacerbations; however, this data was not amenable to meta-analysis due to unreported data (table 5). Both studies observed lower rates of minor/moderate asthma exacerbations in the intervention group compared with the control group. In SMITH et al. [24], the rate was 0.36 versus $0.75(\mathrm{p}=0.24)$ and in SYK et al. [14], 0.1 versus 0.325 events per person year respectively ( $\mathrm{p}$-value not reported).

\section{Composite of all exacerbations and failure rates}

Three studies reported composite outcomes that were considered to be broadly similar and represent what may be termed "treatment failure" (table 5). In SмITH et al. [24] and Sүк et al. [14] this was "any major or minor exacerbation", while in CALHOUN et al. [13] it was exacerbation or any loss of control by a variety of measures. A meta-analysis of these studies (fig. 1c) showed a statistically significant effect in favour of using FeNO-guided management in adults, with a rate ratio of 0.53 (95\% CI $0.46-0.61 ; \mathrm{p}<0.00001)$. However, due to high degree of heterogeneity in composite outcomes, the effect is therefore liable to high risk of bias.

\section{ICS use}

Four studies reported some data on ICS use $[13,14,24,25]$; however, outcomes were not reported in a standardised manner (table 5). As shown in figure 1d, a meta-analysis using the standardised mean difference analysis showed a beneficial overall effect of -0.24 (95\% CI -0.56-0.07) in favour of FeNO-guided management; however, the findings were not statistically significant $(\mathrm{p}=0.13)$.

\section{Relationship between ICS use, step-up/step-down protocol and exacerbations}

A post hoc analysis was undertaken to examine the relationship between ICS use, exacerbations and which step-up/step-down approach was used. A summary of the data is presented in table 6. Two studies that used FeNO levels in conjunction with symptoms showed a statistically significant decrease in ICS use in the FeNO-guided management groups and a nonsignificant decrease in any type of exacerbation [24, 25], thus indicating improved management overall. By contrast, the studies which managed asthma based on FeNO levels alone were less clear. SYK et al. [14] reported no change in ICS use and a nonsignificant decrease in moderate exacerbation and a nonsignificant increase in severe exacerbation, but a significant decrease in any exacerbation. CALHOUn et al. [13] reported no difference in ICS use and exacerbations.

Other outcomes

Health-related quality of life was infrequently reported. Three studies $[13,14,16]$ used versions of the Asthma Quality of Life Questionnaire to measure quality of life. Two studies showed no effect in the global score (pooled standardised mean difference: 0.00 (95\%CI $-0.20-0.20)$; $\mathrm{p}=0.96)[13,16]$. However, one study investigated domains and found a statistically significant difference in the symptoms score ( $p=0.041$ ) with a between group difference in change from baseline of 0.10 in favour of FeNO management [14]. Asthma control was reported in all studies, but showed no statistically significant difference. Further details on other outcomes are summarised in online supplementary appendix 3.

\section{Efficacy of FeNo in pregnant women}

One study reported the efficacy of FeNO-guided management of asthma in pregnant women [26]. The composite outcome of all exacerbations was statistically significantly reduced in the intervention arm, with an incidence rate ratio of 0.496 per pregnancy (95\% CI $0.325-0.755 ; \mathrm{p}=0.001)$. This difference was mostly 
TABLE 5 Exacerbations and inhaled corticosteroid (ICS) use in adult patients with or without fractional exhaled nitric oxide (FeNo)-guided management

\begin{tabular}{|c|c|c|c|c|c|c|c|}
\hline $\begin{array}{l}\text { First author } \\
\text { [ref.] }\end{array}$ & Time of outcome & Definition of outcomes & Subjects $\mathrm{n}$ & $\begin{array}{l}\text { Exacerbations per } \\
\text { person year }\end{array}$ & $\begin{array}{l}\text { Between group } \\
\text { comparison }\end{array}$ & ICS use & $\begin{array}{l}\text { Between group } \\
\text { difference }\end{array}$ \\
\hline \multirow[t]{5}{*}{ SмITH [24] } & \multirow[t]{5}{*}{$\begin{array}{l}\text { 3-12 months optimisation } \\
\text { (exacerbation rates } \\
\text { not reported for this } \\
\text { period) plus } 12 \text { months } \\
\text { titration }\end{array}$} & $\begin{array}{l}\text { Minor: global daily asthma score } \\
\text { of two on } \geqslant 2 \text { consecutive days }\end{array}$ & 94 & $\begin{array}{l}\text { Intervention } \\
\text { group }{ }^{+}: 0.36 \\
\text { Control } \\
\text { group }{ }^{+}: 0.75\end{array}$ & $p=0.24$ & $\begin{array}{l}\text { Final value ICS use } \\
\text { Intervention } \\
\text { Baseline: mean } \\
\quad 411 \mu \mathrm{g} \text { per day } \\
(95 \% \mathrm{Cl} 344-478)\end{array}$ & $\begin{array}{l}\text { Mean difference } \\
-270 \mu \mathrm{g} \text { per day } \\
(95 \% \mathrm{Cl}-112--430 \\
\mathrm{p}=0.003)\end{array}$ \\
\hline & & $\begin{array}{l}\text { Major: global daily asthma score } \\
\text { of three on } \geqslant 2 \text { consecutive days } \\
\text { (or in } 1 \text { day, in the context of a } \\
\text { minor exacerbation) }\end{array}$ & & $\begin{array}{l}\text { Intervention } \\
\text { group }{ }^{+}: 0.13 \\
\text { Control } \\
\text { group }{ }^{+}: 0.14\end{array}$ & $p=0.91$ & $\begin{array}{l}\text { End of phase 2: } \\
\text { mean } 370 \mu \mathrm{g} \\
\text { per day } \\
(95 \% \mathrm{Cl} 263-477)\end{array}$ & \\
\hline & & $\begin{array}{l}\text { Major exacerbation or medical } \\
\text { emergency: global daily asthma } \\
\text { score }^{\text {Tी }} \text { of four in } 1 \text { day }\end{array}$ & & & & $\begin{array}{l}\text { Control } \\
\text { Baseline: mean } \\
\quad 491 \mu \mathrm{g} \text { per day }\end{array}$ & \\
\hline & & Any minor or major exacerbation & & $\begin{array}{l}\text { Intervention } \\
\text { group: } 0.49 \text { (95\% } \\
\text { Cl 0.20-0.78) } \\
\text { Control group: } \\
0.90(95 \% \\
\text { Cl } 0.31-1.49]\end{array}$ & $\begin{array}{l}-45.6 \% \\
(95 \% \mathrm{Cl}-78.6-54.5 \\
p=0.27) \mathrm{NS}\end{array}$ & $\begin{array}{l}(95 \% \mathrm{Cl} 403-579) \\
\text { End of phase } 2: \\
\text { mean } 641 \mu \mathrm{g} \\
\text { per day } \\
(95 \% \mathrm{Cl} 526-756)\end{array}$ & \\
\hline & & Course of oral prednisone & & $\begin{array}{l}\text { Intervention } \\
\text { group: } 0.48 \\
\text { Control group: } 0.60\end{array}$ & $p=0.60$ & & \\
\hline SHAW [25] & 12 months & Course of OCS or antibiotics & 118 & $\begin{array}{l}\text { Intervention } \\
\text { group: } \\
0.33 \text { (sD 0.69) } \\
\text { Control group: } \\
0.42 \text { (sD 0.79) }\end{array}$ & $\begin{array}{l}-21 \%(95 \% \\
\mathrm{Cl}-57-43 \%, p=0.43)\end{array}$ & $\begin{array}{l}\text { Final value ICS use } \\
\text { Intervention: } 557 \mu \mathrm{g} \\
\text { Control: } 895 \mu \mathrm{g}\end{array}$ & $\begin{array}{l}\text { Mean difference } \\
-338 \mu \mathrm{g} \text { per day } \\
(95 \% \mathrm{Cl}-640--37 \mu \mathrm{g} \text {, } \\
\mathrm{p}=0.028) \\
\text { Total used in } \\
\text { study (AUC): } \\
11 \% \text { greater in } \\
\text { FeNo group ( } 95 \% \\
\mathrm{Cl}-15-37 \%)\end{array}$ \\
\hline \multirow[t]{3}{*}{ SYK [14] } & \multirow[t]{3}{*}{$\begin{array}{l}\text { End-points analysed } \\
\text { from visit } 2 \text { to visit } \\
6 \text { ( } 2-4 \text { weeks, } \\
12 \text { months) }\end{array}$} & $\begin{array}{l}\text { Moderate exacerbation: need to } \\
\text { step-up controller treatment } \\
\text { for at least } 2 \text { days with or } \\
\text { without clinic visit } \\
\text { Prophylactic use before pollen } \\
\text { season excluded }\end{array}$ & 165 & $\begin{array}{l}\text { Intervention } \\
\text { group: } 0.1 \\
\text { Control } \\
\text { group: } 0.325\end{array}$ & NR & $\begin{array}{l}\text { ICS use } \text { Iๆ } \\
\text { Intervention } \\
\text { Median } 0 \\
\text { (IQR -400-400) } \\
\text { Baseline: mean } \\
604 \text { (SE 370) }\end{array}$ & 0.945 \\
\hline & & $\begin{array}{l}\text { Severe exacerbation }{ }^{\# \#} \text { : worsening } \\
\text { requiring a course of OCS }\end{array}$ & & $\begin{array}{l}\text { Intervention } \\
\text { group: } 0.113 \\
\text { Control group: } \\
0.0875\end{array}$ & NS & $\begin{array}{l}\text { Final value: } \\
\quad 586 \text { (SE 454) } \\
\text { Control } \\
0 \text { (IQR }-200-200 \text { ) }\end{array}$ & \\
\hline & & Moderate or severe exacerbation & & $\begin{array}{l}\text { Intervention } \\
\text { group: } 0.22 \\
\text { Control group: } 0.41\end{array}$ & $p=0.024$ & $\begin{array}{l}\text { Baseline: mean } \\
626 \text { (SE 391) } \\
\text { Final value: } \\
540 \text { (SE 317) }\end{array}$ & \\
\hline
\end{tabular}




\begin{tabular}{|c|c|c|c|c|c|c|c|}
\hline $\begin{array}{l}\text { First author } \\
\text { [ref.] }\end{array}$ & Time of outcome & Definition of outcomes & Subjects $\mathrm{n}$ & $\begin{array}{l}\text { Exacerbations per } \\
\text { person year }\end{array}$ & $\begin{array}{l}\text { Between group } \\
\text { comparison }\end{array}$ & ICS use & $\begin{array}{c}\text { Between group } \\
\text { difference }\end{array}$ \\
\hline CaLhoun [13] & 9 months & $\begin{array}{l}\text { Exacerbation: unscheduled medical } \\
\text { contact for increased asthma } \\
\text { symptoms that results in the use } \\
\text { of OCS, increased ICS or } \\
\text { additional medication for asthma } \\
\text { Treatment failure defined as } \\
\text { exacerbation or loss of control }\end{array}$ & 229 & $\begin{array}{c}\text { Intervention group: } \\
0.21 \text { (97.5\% } \\
\text { Cl 0.1-0.32) } \\
\text { Control group: } \\
0.23 \text { (97.5\% } \\
\mathrm{Cl} 0.1-0.37 \text { ) } \\
\text { Intervention group: } \\
0.27 \text { (97.5\% Cl } \\
0.14-0.39 \text { ) } \\
\text { Control group: } \\
0.43 \text { (97.5\% Cl } \\
0.23-0.64)\end{array}$ & "Were not different" & $\begin{array}{l}\text { ICS use lunclear if } \\
\text { mean over whole study } \\
\text { or final value }{ }^{f} \\
\text { Intervention } \\
\text { Mean } 1617 \mu \mathrm{g} \cdot \text { month }^{-1} \\
\text { Control } \\
\text { Mean } 1610 \mu \mathrm{g} \cdot \text { month }^{-1}\end{array}$ & NR \\
\hline \multirow[t]{2}{*}{ HoNKOOP [16] } & \multirow[t]{2}{*}{12 months } & $\begin{array}{l}\text { Severe exacerbation: course of oral } \\
\text { prednisone, hospitalisation } \\
\text { and/or emergency } \\
\text { department visit }\end{array}$ & \multirow[t]{2}{*}{611} & $\begin{array}{l}\text { Intervention group: } \\
0.19(95 \% \\
\text { Cl } 0.11-0.29) \\
\text { Control group } \\
\text { Strict: } 0.29(95 \% \\
\text { Cl } 0.17-0.40) \\
\text { Sufficient: } 0.29 \\
\text { (95\% Cl } \\
0.15-0.43)\end{array}$ & $\begin{array}{l}\text { Odds ratio versus } \\
\text { Strict: } 0.64(95 \% \\
\text { Cl } 0.27-1.56) \\
\text { Sufficient: } 0.79 \\
\text { (95\% Cl } 0.32-1.92 \text { ) }\end{array}$ & \multirow[t]{2}{*}{ NR } & \multirow[t]{2}{*}{ NR } \\
\hline & & $\begin{array}{l}\text { Unscheduled healthcare utilisation: } \\
\text { hospitalisation and/or emergency } \\
\text { department visit }\end{array}$ & & $\begin{array}{l}\text { Number of visits } \\
\text { Intervention } \\
\text { group: } 3 \\
\text { Controlled asthma: } \\
\text { strict } 5 \\
\text { Partly controlled } \\
\text { asthma: } \\
\text { sufficient } 9\end{array}$ & $\begin{array}{l}\text { Odds ratio versus } \\
\text { Strict: } 0.61(95 \% \\
\text { Cl } 0.14-2.58) \\
\text { Sufficient: } \\
\quad 0.37 \text { (95\% } \\
\text { Cl } 0.10-1.38 \text { ) }\end{array}$ & & \\
\hline
\end{tabular}

NS: nonsignificant difference; OCS: oral corticosteroid; AUC: area under curve; NR: not reported; IQR: interquartile range; PEFR: peak expiratory flow rate. ${ }^{\#}$ : Expressed as intervention minus control (negative values indicate lower FeNo). ๆ. Asthma scores were as follows. 0 (stable): morning PEFR $>75 \%$ of best PEFR in 14 -day run-in period without deterioration in any symptom scores. 1 (mildly unstable): one or more of the following al bronchodilator use on two or more occasions in $24 \mathrm{~h}$ more than the rounded mean number of occasions during the run-in period; b) increase in symptom score of 1 point or more as compared with rounded mean during run-in period; cl onset of or increase in nocturnal waking by one or more times in the previous seven nights more than rounded mean number of times during the run-in period, or morning PEFR of $61-75 \%$ without deterioration in any of the above categories. 2 (minor deterioration): morning PEFR of $61-75 \%$ of best PEFR during the run-in period and one or more criteria for an asthma score of 1; or morning PEFR of $41-60 \%$ without deterioration in any criteria for an asthma score of 1.3 (major deterioration): morning PEFR of 41-60\% of best PEFR during run-in period and one or more criteria for an asthma score of 1.4 (major exacerbation or medical emergency): morning PEFR of $40 \%$ or less than best PEFR during run-in period regardless of symptoms, or attendance at clinician's office or emergency department because of severe asthma. ${ }^{+}$: Estimated off graph. ${ }^{\S}$ : Fluticasone or the equivalent. ${ }^{f}$ : Beclomethasone diproprionate or equivalent. \#\#: American Thoracic Society/European Respiratory Society Task Force Criteria 2009. ${ }^{\text {Iा : }}$ Budesonide equivalent. ${ }^{++}$: At-home measurements: 1) Pre-bronchodilator AM peak expiratory flow (PEF) of $<65 \%$ of baseline on two consecutive mornings, scheduled measurements. 2) Post-bronchodilator PEF of $<80 \%$ of baseline despite 60 min of rescue $\beta$-agonist treatment. 3) Post-bronchodilator PEF may be taken at any time of day, an increase in albuterol use of more than 8 puffs per $24 \mathrm{~h}$ over baseline use for a period of $48 \mathrm{~h}$, or more than 16 puffs per $24 \mathrm{~h}$ for more than $48 \mathrm{~h}$. In-clinic measurements: 1) Pre-bronchodilator forced expiratory volume in $1 \mathrm{~s}(\mathrm{FEV} 1)$ values on two consecutive sets of spirometric determinations, measured $24-72 \mathrm{~h}$ apart, that are $<80 \%$ of the baseline pre-bronchodilator value (baseline value for adherence period: FEV1 value at visit 3; baseline for randomisation period: FEV 1 value at visit 4 ). All participants found to have an FEV1 of $<80 \%$ of baseline at any centre visit but who are not considered to meet treatment failure or exacerbation criteria must be seen again within $72 \mathrm{~h}$ to have FEV1 measured. 2) Physician judgment for patient safety. 3) Patient dissatisfaction with asthma control achieved by study regimen. 4) Requirement for open-label ICSs or another (nonsystemic 


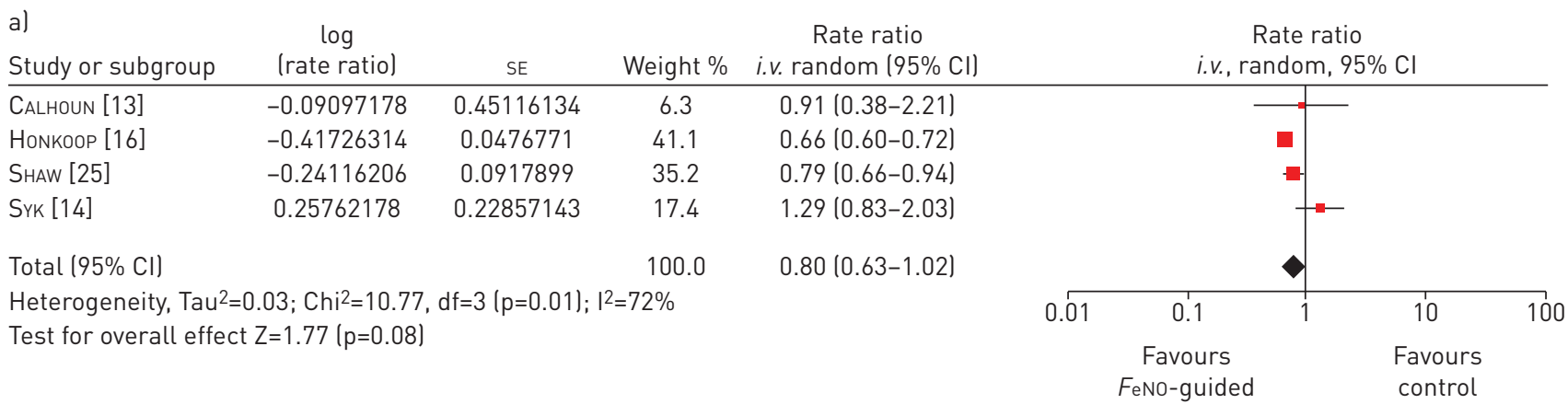

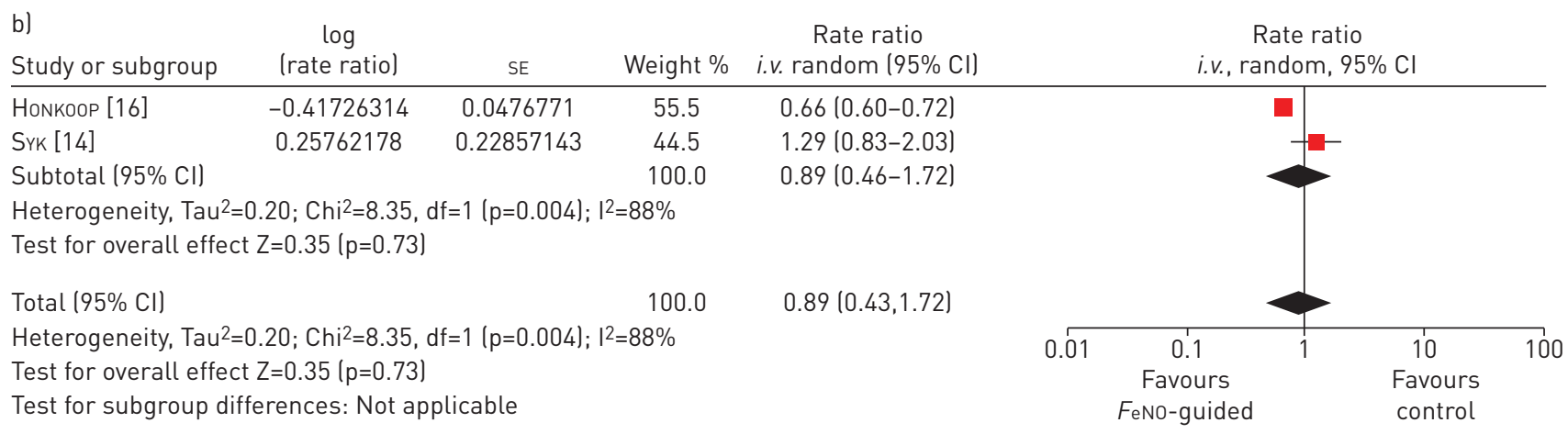

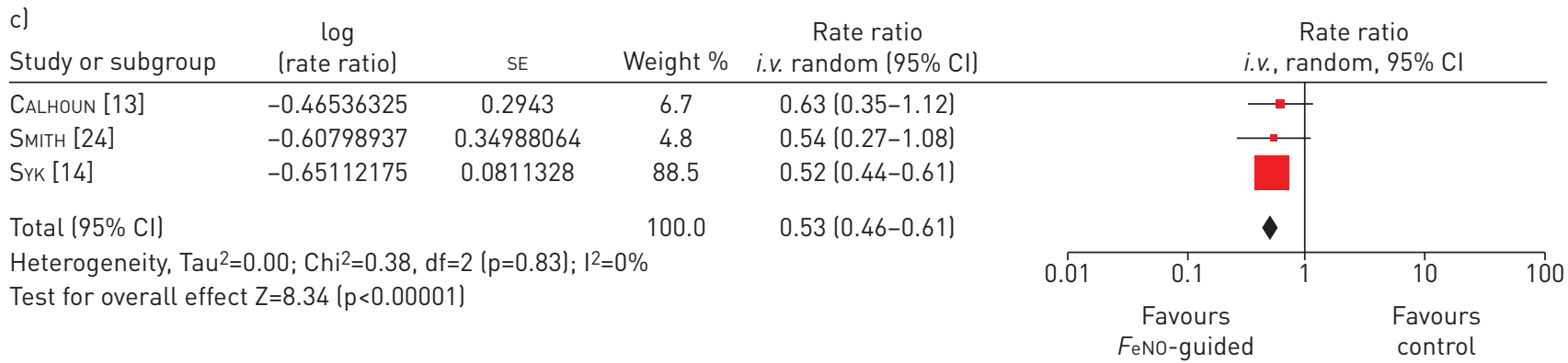

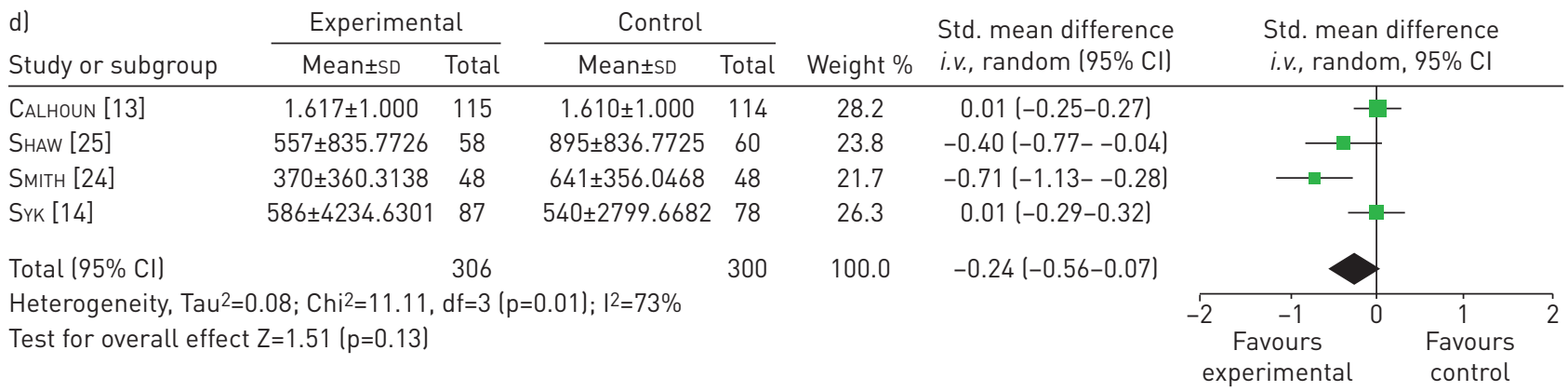

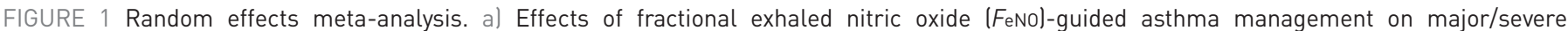
exacerbation rates. b) Number of severe exacerbations resulting in the use of oral corticosteroids. c) Effects of FeNo-guided asthma management

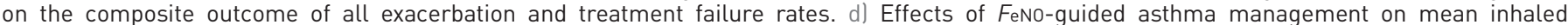
corticosteroids use (standardised (Std) mean difference analysis).

driven by the rate of OCS use and the rate of doctors' visits during pregnancy (table 7). Mean OCS use in the FeNO and control arm was 0.08 (95\% CI $0.03-0.133$ ) and 0.19 (95\% CI 0.08-0.31), respectively $(\mathrm{p}=0.042)$. Similarly, the rate of doctors' visits was $0.26(95 \%$ CI $0.16-0.36)$ in the FeNO arm and 0.56 (95\% CI $0.40-0.72)$ in the control arm with a p-value of 0.002 in favour of FeNO management. Other components of the exacerbation outcome (hospitalisations and emergency room/labour ward visits) did not differ between groups. The change in mean value from baseline to final visit for ICS use decreased by 


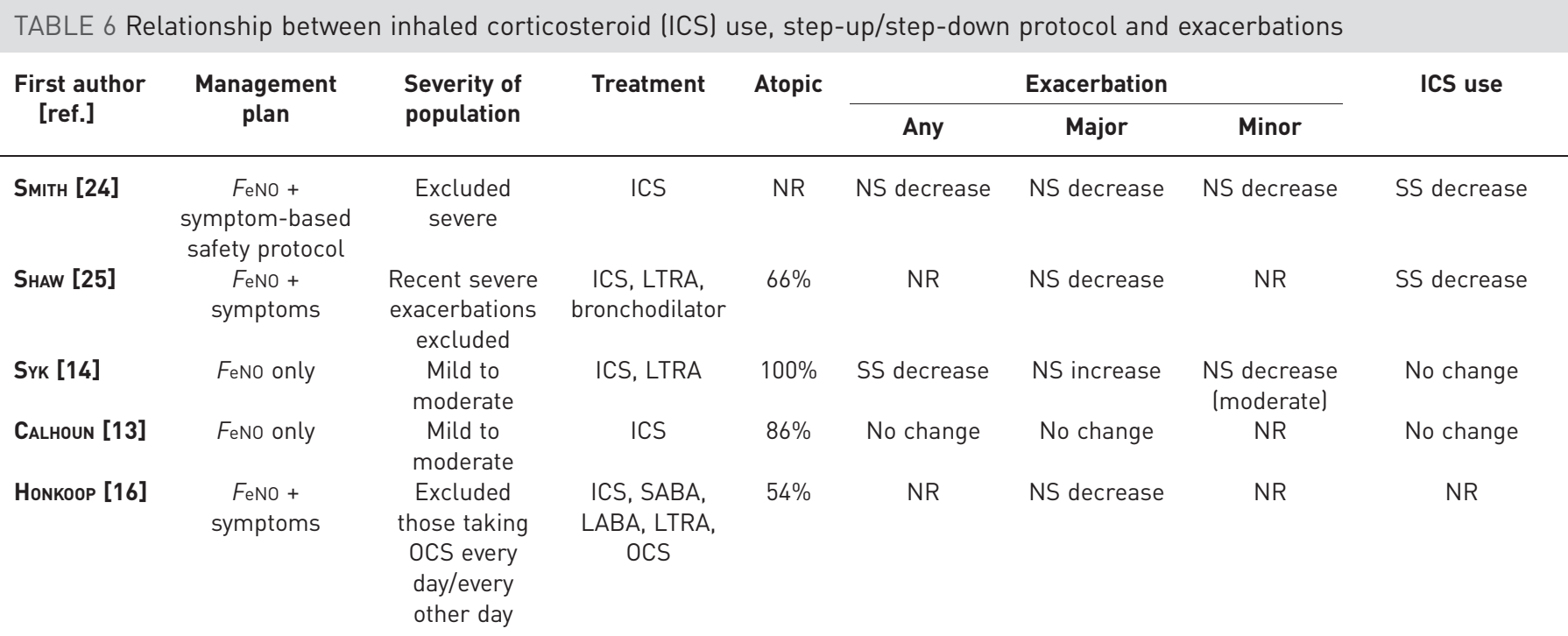

FeNO: fractional exhaled nitric oxide; NR: not reported; NS: nonsignificant; SS: statistically significant; LTRA: leukotriene receptor antagonist; OCS: oral corticosteroid; SABA: short-acting $\beta_{2}$-agonist; LABA: long-acting $\beta_{2}$-agonist.

$210 \mu \mathrm{g} \cdot \mathrm{day}^{-1}$ in the intervention arm and increased by $50 \mu \mathrm{g} \cdot \mathrm{day}^{-1}$ in the control arm. The difference was statistically significant in favour of FeNO management $(\mathrm{p}=0.043)$. However, overall more patients received ICS (68\% versus $42 \%$ ) in the FeNO group than in the control group by the end of the study. Other outcomes are summarised in table 7.

\section{Discussion}

In this systematic review, six RCTs were identified that assessed the use of FeNO for the management of asthma in adults $[13,14,16,24-26]$. In general, using exploratory meta-analysis, a fall in exacerbation rates per person year were observed, but none were statistically significant apart from the composite of all exacerbations and failure rates. However, the findings should be interpreted with caution due to the high degree of heterogeneity in the outcome definition. The effects on ICS use were heterogeneous, although the direction of the effect was towards a decrease in ICS use. The effect on healthcare utilisation was not statistically significant; however, as this outcome was only reported in one low quality study [16], to base any conclusion on this could be misleading. The use of $F$ eNO to guide asthma management in pregnant women in the second trimester appears to be as effective, if not more so, than in other adults [26], and appears to reduce exacerbations and ICS use, but by the end of the study more patients in FeNO group had received ICS. The differences in outcome between studies may have occurred due to some step-up/ step-down protocols being better at decreasing ICS use than others, or may be due to the characteristics of the study populations. Other potential factors as to why the FeNO monitoring studies have been predominately negative could be due to the difference in severity of asthma at baseline, different treatment strategies used (i.e. some studies controlled only ICS while some also controlled other medications), differences in the number and points of FeNO cut-off used, and also the comparator groups did not all use the same algorithm.

There are at least two previous systematic reviews on the effectiveness of FeNO monitoring to guide management [9, 11]. Petsky et al. [9] compared adjustments of asthma therapy based on FeNO with conventional methods (typically clinical symptoms and spirometry). The review suggested some benefits associated with FeNO for several outcomes, in particular the number of subjects with $>1$ exacerbation, exacerbation rates, $\mathrm{FEV}_{1} \%$ predicted at final visit and geometric change in FeNO from baseline; however, none of these results were statistically conclusive. FeNO appeared to have some beneficial effect on symptom score (mean difference: $-0.14,95 \%$ CI $-0.42-0.14$ ) and lowered ICS dose (mean difference: $-450.03 \mu \mathrm{g}, 95 \%$ CI $-676.73--223.34 \mu \mathrm{g}$ ). Furthermore, there was substantial clinical heterogeneity among the study cohorts, with no two studies using exactly the same step-up/step-down protocols. There is some agreement between the review by РЕTSKY et al. [9] and our own review, especially relating to the lack of statistically significant effects in most outcomes. The strength of our review lies in the inclusion of subsequently published studies (CAlHoun et al. [13], Syk et al. [14] and Honkoop et al. [16]), the focus on exacerbation rates rather than number of people with an exacerbation, and the prior separation of 
TABLE 7 Pregnant women: all outcomes

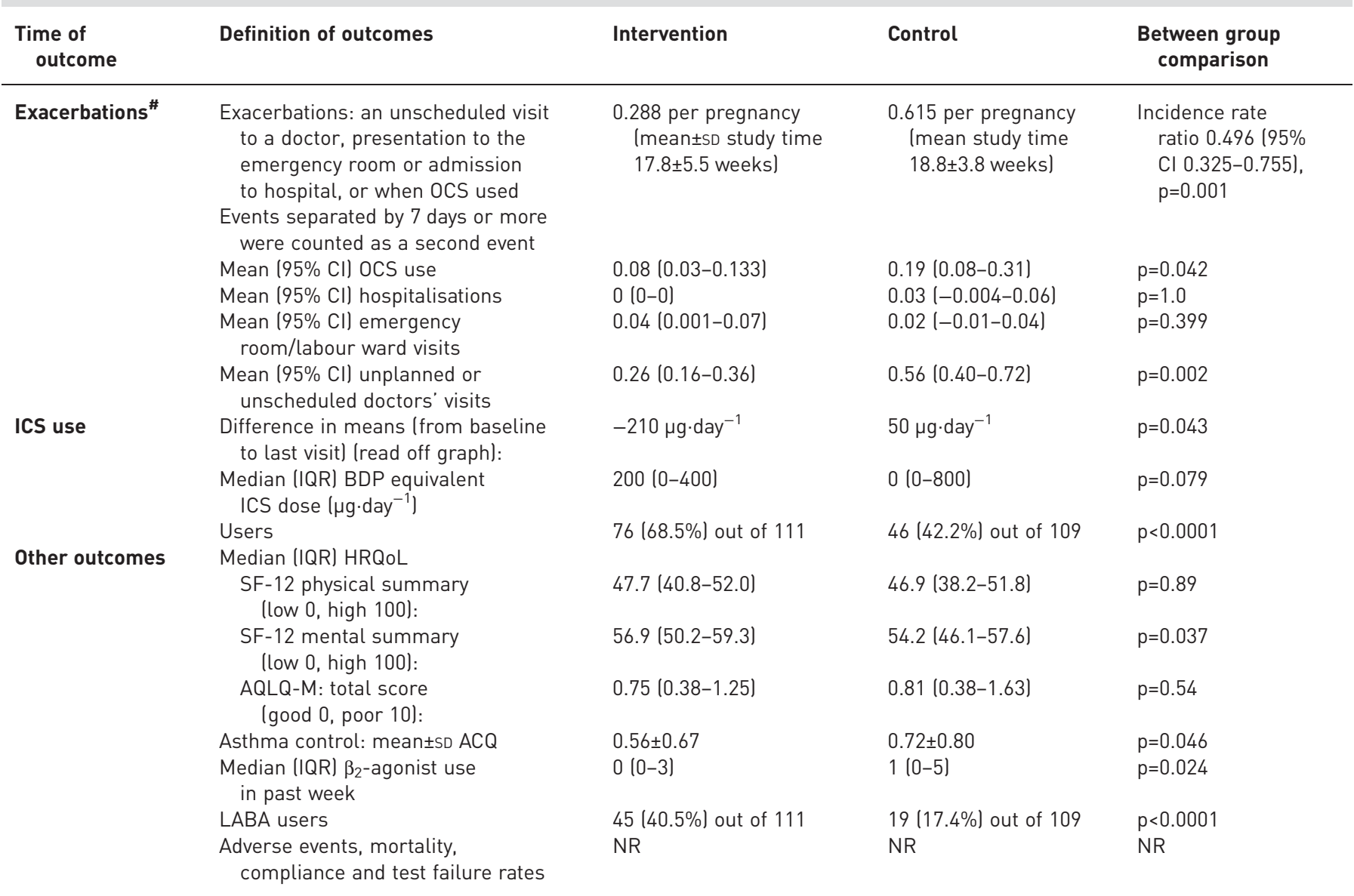

OCS: oral corticosteroids; IQR: interquartile range; BDP: beclomethasone diproprionate; ICS: inhaled corticosteroid; HRQoL: health-related quality of life; SF-12: short form 12; AQLQ-M: Asthma Quality of Life Questionnaire-Marks; ACQ: Asthma Control Questionnaire; LABA: long-acting $\beta_{2}$-agonist; NR: not reported. " : time of outcome was monthly until birth (maximum 30 weeks). Information from [26].

pregnant women into a different subgroup. The second review by Donohue and JAIN [11] updated the meta-analyses of the number of patients with $>1$ exacerbation and exacerbation rates from the aforementioned Cochrane review [9], and included a study in pregnant women [26]. Inclusion of this study resulted in improvements on all measures of exacerbations (mean difference: $-0.27,95 \%$ CI $-0.42-$ -0.12 ), and the relative rate of asthma exacerbations (relative rate: $0.57,95 \%$ CI $0.41-0.80$ ). However, since it is known that pregnancy can substantially affect the course of asthma [12], it was arguably inappropriate to include the cohort of pregnant women in a meta-analysis of adults with asthma.

One of the putative benefits of using FeNO for the management of asthma is the identification of patients for whom increased ICS use will not improve control. These patients are likely to present with symptoms, which would indicate an increase in pharmaceutical management under standard clinical guidelines, and under most of the FeNO protocols that have been studied to date, whereas they may be better treated with other asthma control medications. A key limitation is therefore the paucity of studies that allowed step-down of ICS to be performed on the basis of low FeNO values alone. Only two studies [13, 14] and the study in pregnant women [26] included such a strategy, and only Powell et al. [26] made provision for adjusting other treatments which may offer superior control in these patients in response to their reported symptomatology. We did not plan or perform a sensitivity analysis of this data, but did present a rudimentary analysis of the relationship between ICS use, management protocols and exacerbations (table 6). It is interesting to note that the two studies that managed patients on the basis of FeNO only (Syk et al. [14] and CAlHoun et al. [13]) did not report any change in ICS use, which is perhaps contrary to expectations, or in severe exacerbations. However, SYK et al. [14] did report a fall in exacerbations overall. In comparison, the two studies that managed patients on the basis of FeNO and symptoms (SMITH et al. [24] and SHAw et al. [25]) reported a statistically significant decrease in ICS use and a nonsignificant decrease in exacerbations. This perhaps indicates a shift in treatment patterns, with better targeting of 
treatment with the addition of FeNO to the patients who will benefit most. In addition, although there was no significant difference in compliance with treatment between the FeNO management and control group, there is a potential that FeNO may help improve compliance with ICS use.

There are a number of limitations to our review which warrant caution in its interpretation to clinical practice. The evidence from the included studies are of low quality and there is significant heterogeneity in all aspects of study design across the studies, including patient characteristics, outcome definitions, FeNO cut-off points and in management protocols, hence an exploratory meta-analysis was used to overcome these differences. In addition, the management plan used in some studies did not reflect real life practice, for example in the study by SMITH et al. [24], long-acting $\beta_{2}$-agonist (LABA) was not used and patients underwent a step-down therapy approach in the pre-study phase. It is noteworthy that LABA in combination with ICS are key steps in asthma management. The equivalence of devices is assumed and this may not hold true in practice. As such, FeNO cut-off values as reported in the primary research may not be applicable to measurements using other devices. Smoking affects FeNO levels and majority of the patients in this review were nonsmokers, hence it is not clear if the results can be generalised to the smoking population. Also, the average age of patients in this review was around 40 years old. However, the majority of asthma deaths occur in older people with severe disease. All the included studies recruited patients that were stable during the run-in period and excluded the more severe/difficult patients with recent hospital admissions. So, by definition, some of the real life "difficult" patients, who require more help, were excluded. Finally, the criteria used for the diagnosis of asthma across the included studies varied with limited data and as recent studies have reported the potential of overdiagnosis of asthma, this may have implications for the results. It is important to note that these limitations are principally sourced in the evidence base, rather than the methods used to interrogate and evaluate it. One should also bear in mind that the addition of FeNO to the current management strategy will require change in organisation and to the philosophy of care in self-management.

\section{Conclusion}

FeNO guided management showed no statistically significant benefit in terms of severe exacerbations or ICS use, but showed a statistically significant reduction in exacerbations of any severity. Due to heterogeneity in the studies it was not possible to draw any firm conclusions as to which management protocol or cut-off points offer the best efficacy. Further research is required to investigate the best way to use FeNO in the management of asthma, which management protocol and cut-offs to use; to establish which patient groups are likely to benefit from FeNO monitoring, e.g. individuals with atopy, frequent exacerbations or those with poor adherence; and how treatment effect will progress over time. Larger, well designed RCT studies, taking into account issues such as severity as defined by previous exacerbations, blinding and approximating to routine care are warranted to clearly define the role of FeNO in clinical practice.

\section{Acknowledgements}

We would like to thank John W. Stevens (School of Health and Related Research, University of Sheffield, Sheffield, UK) for providing statistical support.

\section{References}

1 Royal College of Physicians. Why Asthma Still Kills: the National Review of Asthma Deaths (NRAD). www. asthma.org.uk/globalassets/campaigns/nrad-full-report.pdf Date last accessed: June 1, 2015. Date last updated: May, 2014.

2 British Thoracic Society (BTS). The Burden of Lung Disease. 2nd Edn. A statistics report from the British Thoracic Society. www.brit-thoracic.org.uk/document-library/delivery-of-respiratory-care/burden-of-lung-disease/ burden-of-lung-disease-2006/ Date last accessed: accessed 1 June 2015. Date last updated: 2006.

3 Dahl R. Systemic side effects of inhaled corticosteroids in patients with asthma. Respir Med 2006; 100: 1307-1317.

4 British Thoracic Society (BTS), Scottish Intercollegiate Guidelines Network (SIGN). British Guideline on the Management of Asthma: a National Clinical Guideline. Revised 2014. www.brit-thoracic.org.uk/guidelines-and-quality-standards/asthma-guideline/ Date last accessed: June 2, 2015. Date last updated: October 8, 2014.

5 Dweik RA, Boggs PB, Erzurum SC, et al. An official ATS clinical practice guideline: interpretation of exhaled nitric oxide levels $\left(\mathrm{FE}_{\mathrm{NO}}\right.$ ) for clinical applications. Am J Respir Crit Care Med 2011; 184: 602-615.

6 Schleich FN, Seidel L, Sele J, et al. Exhaled nitric oxide thresholds associated with a sputum eosinophil count $\geqslant 3 \%$ in a cohort of unselected patients with asthma. Thorax 2010; 65: 1039-1044.

7 Pavord ID, Shaw DE, Gibson PG, et al. Inflammometry to assess airway diseases. Lancet 2008; 372: 1017-1019.

8 Berry M, Morgan A, Shaw DE, et al. Pathological features and inhaled corticosteroid response of eosinophilic and non-eosinophilic asthma. Thorax 2007; 62: 1043-1049.

9 Petsky HL, Cates CJ, Li A, et al. Tailored interventions based on exhaled nitric oxide versus clinical symptoms for asthma in children and adults. Cochrane Database Syst Rev 2009; 4: CD006340.

10 Petsky HL, Cates CJ, Lasserson TJ, et al. A systematic review and meta-analysis: tailoring asthma treatment on eosinophilic markers (exhaled nitric oxide or sputum eosinophils) asthma in children and adults. Thorax 2012; 67: 199-208. 
11 Donohue JF, Jain N. Exhaled nitric oxide to predict corticosteroid responsiveness and reduce asthma exacerbation rates. Respir Med 2013; 107: 943-952.

12 Tan KS, Thomson NC. Asthma in pregnancy. Am J Med 2000; 109: 727-733.

13 Calhoun WJ, Ameredes BT, King TS, et al. Comparison of physician-, biomarker-, and symptom-based strategies for adjustment of inhaled corticosteroid therapy in adults with asthma: the BASALT randomized controlled trial. JAMA 2012; 308: 987-997.

14 Syk J, Malinovschi A, Johansson G, et al. Anti-inflammatory treatment of atopic asthma guided by exhaled nitric oxide: a randomized controlled trial. J Allergy Clin Immunol Pract 2013; 1: 639-648.

15 Honkoop P, Loijmans R, Termeer E, et al. A cluster randomized trial comparing strict, partial, and FeNO-guided asthma control strategies in primary care. Eur Respir J 2013; 42: Suppl. 57, abstract 1710.

16 Honkoop PJ, Loijmans RJB, Termeer EH, et al. Symptom- and fraction of exhaled nitric oxide-driven strategies for asthma control: a cluster-randomized trial in primary care. J Allergy Clin Immunol 2015; 135: 682-688.

17 National Institute for Health and Care Excellence (NICE). Measuring fractional exhaled nitric oxide concentration in asthma: NIOX MINO, NIOX VERO and NObreath. NICE diagnostics guidance 12. www.nice.org.uk/guidance/dg12 Date last accessed: June 10, 2015. Date last updated: April, 2014.

18 Harnan SE, Tappenden P, Essat M, et al. Measurement of exhaled nitric oxide concentration in asthma: a systematic review and economic evaluation of NIOX MINO, NIOX VERO and NObreath. Health Technol Assess 2015; 19: 1-330.

19 Moher D, Liberati A, Tetzlaff J, et al. Preferred reporting items for systematic reviews and meta-analyses: the PRISMA statement. PLoS Med 2009; 6: e1000097.

20 American Thoracic Society, European Respiratory Society. ATS/ERS recommendations for standardized procedures for the online and offline measurement of exhaled lower respiratory nitric oxide and nasal nitric oxide, 2005. Am J Respir Crit Care Med 2005; 171: 912-930.

21 Gomersall $\mathrm{T}$, Harnan $\mathrm{S}$, Essat $\mathrm{M}$, et al. A systematic review of fractional exhaled nitric oxide in the routine management of childhood asthma. Pediatr Pulmonol 2015 [In press; DOI: 10.1002/ppul.23371].

22 Higgins JPT, Green S, eds. Cochrane Handbook for Systematic Reviews of Interventions. Version 5.1.0. The Cochrane Collaboration, 2011.

23 Centre for Reviews and Dissemination. Systematic Reviews. CRD's Guidance for Undertaking Reviews in Health Care. York, Centre for Reviews and Dissemination, 2009.

24 Smith $\mathrm{AD}$, Cowan JO, Brassett KP, et al. Use of exhaled nitric oxide measurements to guide treatment in chronic asthma. N Engl J Med 2005; 352: 2163-2173.

25 Shaw DE, Berry MA, Thomas M, et al. The use of exhaled nitric oxide to guide asthma management: a randomized controlled trial. Am J Respir Crit Care Med 2007; 176: 231-237.

26 Powell H, Murphy VE, Taylor DR, et al. Management of asthma in pregnancy guided by measurement of fraction of exhaled nitric oxide: a double-blind, randomised controlled trial. Lancet 2011; 378: 983-990.

27 Standards for the diagnosis and care of patients with chronic obstructive pulmonary disease (COPD) and asthma. Am Rev Respir Dis 1987; 136: 225-244. 